\title{
THE POTENTIAL FOR CREATIVITY OF PUPILS IN TECHNICAL EDUCATION AT THE SECOND LEVEL PRIMARY SCHOOLS
}

\author{
Pavel PECINA - Silvie MALÁ
}

Abstract: Article is devoted to issues of technical creativity of pupils at the second level elementary school. After the initial definition of the issue is focusing on the technical challenges in creative teaching practices at the second level primary schools.

Keywords: Creativity, technical creativity, creative role.

\section{MOŽNOSTI ROZVOJE KREATIVITY ŽÁKŮ V TECHNICKÉM VZDĚLÁVÁNÍ NA DRUHÉM STUPNI ZÁKLADNÍCH ŠKOL}

Resume: Článek je věnován problematice technické tvořivosti žáků na druhém stupni ZŠ. Po úvodním vymezeni problematiky je pozornost zaměrena na technické tvořivé úkoly ve výuce praktických činností na druhém stupni základních škol.

Kličová slova: Tvořivost, technická tvořivost, tvořivé úlohy.

Úvod

Problematika tvořivosti (kreativity) žáků je tak významným fenoménem, že je na ni zaměřena řada studií (Zelina, Zelinová, 1990, Kožuchová, 1995, Maňák, 1998, Lokšová, Lokša, 2003, Pecina, 2008 a další.). Tvořivost je považována za nejvyšší a nejuznávanější stupeň aktivity žáka. Obecných definic tvořivosti je mnoho (řádově několik desítek). Všechny tyto definice se prolínají ve dvou momentechspojují projev tvořivosti žáka (člověka) s novostí (originálností) a užitečnostní (novostí) a to jak v subjektivní tak objektivní rovině (Lokšsová, Lokša, 2003). Tvořivost můžeme definovat jako jev, při kterém žák (žáci) správně a účelně řeší problémové situace (v teoretické i praktické rovině) projevující se ve vzniku něčeho nového a zároveň účelného. Je to $\mathrm{v}$ různé míře vlastnost každého žáka, kterou je třeba podle možností rozvíjet ve všech možných směrech.“(Pecina, 2005, str. 19). Tvořivost je aktivita, která přináší dosud neznámá řešení a společensky hodnotné výtvory.“( Kožuchová, 1995). Podle M. Kožuchové (1995) současné psychologické koncepce rozumí tvořivým procesem schopnost osobitým způsobem řešit problémy.

Technická tvořivost je určitým specifickým typem tvořivosti, který se vztahuje na oblast velmi rozsáhlého a složitého světa, který označujeme pojmem „technika“. Pojem technika (z řeckého techné- znalost, obratnost $\mathrm{v}$ práci řemeslné i umělecké) označujeme velmi rozsáhlou, složitou a těžko vymezitelnou oblast světa, v níž existujeme (Kropáč, 2004). Proto také v pramenech nalézáme různé definice tohoto pojmu. Ve výuce technických předmětů lze využít jednoduchou definici J. Kropáče:

„Technika je soubor ve prospěch člověka vytvořených prostředků lidské činnosti a souhrn postupů a způsobů činností prováděných při jejich výrobě a užití. „(Kropáč, 2004. s. 23).

M. Kožuchová s odkazem na další prameny vymezuje pojem technické tvořivosti takto: "Technickou tvořivost můžeme definovat jako schopnost jedince měnit okolní svět a vytvářet nové užitečné hodnoty $v$ oblasti, kterou označujeme jako technika." Techniku přitom chápeme jako technické předměty i procesy (Kožuchová, M., 1995, s. 19). Jiná definice vymezuje technickou tvořivost jako druh činnosti, která spočívá ve správném a účelném řešení materiálního uskutečnění libovolné technické úlohy. Její řešení spočívá ve využití poznatků, získaných v průběhu studia i osobní zkušenost (Stoljarov, 1983). W. Hande (1985) chápe tvořivou technickou činností tu činnost, která se týká techniky a je pro ni charakteristické plné zaujetí žáka technickým objektem poznání a zároveň aktivní a samostatná činnost za účelem dalšího rozvoje techniky. Tato definice se zaměřje na aktivní úlohu žáka $\mathrm{v}$ rámci technické tvořivé práce. Ale je třeba zdůraznit, že žák není špičkovým odborníkem v technické oblasti. Proto nevytvoří dílo, které má velký význam pro rozvoj techniky. Pro rozvoj technické tvořivosti žáka je 
důležitá nová hodnota pro subjekt (žák) nebo skupinu (žáci).

$Z$ analýzy různých pramenů, které řeší tento problém, jsme došli k závěru, že projev technické tvořivosti u žáka (žáků) můžeme chápat ve dvou rovinách:

1. Jako správné a účelné řešení problémových úloh technického charakteru $\mathrm{v}$ teoretické rovině.

2. Při praktické činnosti, kdy žák (žáci) správně a účelně vyřeší problém praktického charakteru při práci s technickými materiály nebo při školním experimentování (např̀. ve fyzice zapojování obvodů, sestavování pokusů,... atd.).

Tvořivost je mnohotvárný jev, na němž se podílí mnoho komponent- myšlenkové operace, inteligence, představivost, obrazotvornost, fantazie. Klíčovou roli mají tvưrčí schopnosti, což jsou výkonnostní dispozice (senzitivita, fluence, flexibilita, redefinice, originalita, elaborace). V. Smékal (1996) rozumí tvořivostí soubor dispozic a způsobilostí a soubor psychických stavů a procesů. V. Švec (1998) se ve své studii zabývá tvưrčími dovednostmi. Uvádí, že tvořivost je složitější kognitivní strukturou, v níž hrají rozhodující roli schopnosti a dovednosti subjektu i další psychické procesy. $\mathrm{V}$ tomto duchu tedy dovednosti chápe jako podmnožinu tvořivosti a poukazuje na patnáct důležitých složek tvořivosti (dispozic a způsobilostí), ke kterým dospěli na základě mnoha výzkumů tvořivosti autoři $\mathrm{W}$. Kirst a U. Dickmayer. Jsou to:

- Pohyblivost (schopnost snadno přejít k novým formám myšlení) .

- Plynulost (schopnost snadno nalézat vhodná řešení).

- Originalita (schopnost vymýšlet netradiční nová řešení).

- Analýza (schopnost rozložit celek na části a umět je definovat).

- Produktivita (schopnost vytvářet nové vazby mezi částmi).

- Konstruování (dovednost uspořádat známe věci do nových celků),

- Přestavba (změna dosavadních souvislostí a vytvoření nových vztahů).

- Uspořádání (nalezení přijatelného způsobu dělení, podle kterého se uspořádají myšlenky).

- Síla vyjadřování (schopnost vyjádřit své nápady).
- Realizace (dovednost vyltvořit plán řešení a úspěšně ho zrealizovat).

- Kombinace (schopnost nalézt souvislosti a nalézt řešení na základě jejich srovnání).

- Transformace (nahrazení určité myšlenky jinou).

- Rozhodování (porovnat různé myšlenky a stanovit další postup).

- Přiřazování (schopnost zkoordinovat myšlenky s podmínkami).

- Organizování (dovednost podřídit př́slušný materiál účelu a cíli).

\section{Možnosti rozvoje tvořivosti žáků $v$ technické vzdělávání na druhém stupni $Z \mathbf{Z S}$}

$\mathrm{V}$ posledních letech byly u nás i $\mathrm{v}$ zahraničí provedeny experimentální výzkumy, které byly zaměřeny na rozvoj technický orientované tvořivosti žáků. M. Kožuchová, Z. Pomšár a I. Kožuch (1997) realizovali experiment na Základní škole v Bratislavě, na základní škole v Kežmarku a na základní škole v Lehote pod Vtáčnikom. Cílem výzkumu bylo zjistit, jaký vliv má zadávání problémových úkolů na rozvoj tvořivosti žáků na 1 . stupni ZŠ. Tř́idy byly rozděleny na experimentální (zde se zadávaly problémové úkoly) a kontrolní (zde se vyučovalo tradičně). Získané výsledky prokázaly, že ve všech faktorech tvořivosti došlo $\mathrm{u}$ experimentálních skupin $\mathrm{k}$ př́růstkům, které se potvrdily na hladině významnosti $1 \%$.

V rámci projektu naší disertační práce (Pecina, 2005) jsme v druhém pololetí školního roku 2003/2004 realizovali experiment na I. Německém zemském gymnáziu v Brně. V něm jsme ověřovali vliv problémové výuky na rozvoj technicky orientované tvořivosti žáků II. ročníku víceletého gymnázia ve fyzice. Do experimentu byly zapojeny 2 třídy- sekunda A a sekunda B. V sekundě A jsme vyučovali tradičními metodami (zejména metodou výkladu) a v sekundě $B$ jsme vyučovali problémovou metodu (metodou řešení problémových otázek a úkolů). Sekunda A tedy byla kontrolní třída a sekunda B byla experimentální třída. Experiment trval celé pololetí (5 měsíců). Sestavili jsme a před zahájením zadali studentům v obou tř́́dách test tvořivosti (pretest) a po skončení experimentu zadali opět stejný test (posttest). Doba mezi zadáváním testu byla dostatečně dlouhá na to, aby zapamatování neovlivnilo výsledky testu. Výsledky prokázaly, že v experimentální skupině došlo ve šech bodech testu ke zlepšení. Studenti dosáhli lepších 
výsledků, avšak u většiny úkolů mezi výsledky nebyly statisticky významné rozdíly ve prospěch problémové výuky. Studenti v kontrolní skupině nedosáhli u žádného z úkolů významnějšího zlepšení. U mnoha úkolů byly výsledky po experimentu nepatrně horší. Domníváme se, že kdyby experiment trval déle (celý školní rok), byly by u experimentální skupiny statisticky významné rozdíly ve prospěch problémové výuky.

J. Novotný a J. Zukerstein (2007) provedli experiment na druhém stupni $Z S$ Š ve výuce praktických činností, ve kterém zjišt’ovali vliv projektové a problémové výuky na rozvoj technicky orientované tvořivosti u žáků 7. ročníku. Experiment proběhl ve 4 trrídách na dvou základních školách v Ústeckém kraji. Žáci byly rozděleni do experimentálních a kontrolních tř́d. Výuka proběhla $\mathrm{v}$ oblasti tématického celku"Práce se dřevem“, který byl realizován na obou školách. Výzkum proběhl od září 2003 do června 2004. Na začátku experimentu proběhlo testování pomocí tvarového skládacího testu (TST) od autora G. A. Lienerta za účelem zjištění úrovně technické tvořivosti. Test byl zkonstruován na zjišt'ování praktické inteligence, tedy schopnosti řešit nové úlohy praktického charakteru. Poté následovala experimentální změna v experimentálních skupinách, která spočívala $\quad \mathrm{v}$ působení projektových a problémových metod výuky. V závěrečné etapě(červen 2004) proběhlo testování (posttest TST) zjištění úrovně technické tvořivosti. Výsledky prokázaly, že u všech skupin došlo $\mathrm{k}$ nárůstu technické tvořivosti o více než $10 \%$. Autoři to vysvětlují tím, že nárůst tvořivosti je u této věkové skupiny běžný. U experimentální skupiny došlo oproti kontrolní skupině k navýšení ještě o $1,6 \%$. U experimentální skupiny tedy došlo knavýšení průměrnému i navýšení u jednotlivých žáků.

Technicky orientovanou tvořivost lze rozvíjet zadáváním rozmanitých problémových úkolů zaměřených na rozvoj tvůrčích schopností a dovedností. M. Kožuchová (1995) uvádí čtyři požadavky, které jsou nutné k rozvoji technické tvořivosti u žáků:

1. Žáci by měli při rozvoji technické tvořivosti využívat vědomosti $z$ technických, ekonomických i prrírodních věd.

2. Musí se seznámit s metodami a postupy, které jim pomohou vyřešit problémy technického charakteru.

3. K technické tvořivé činnosti musí být vhodně motivováni.
4. Žáci mohou řešit pouze ty problémy, které jsou přiměřené jejich schopnostem.

Technické tvořivé úlohy lze členit podle různých hledisek. M Kožuchová (1995) uvádí následující členění:

\section{Konstrukční úlohy}

Konstrukce podle nákresu, při kterém si žáci musí představit technický předmět, který vyrábí a jeho vlastnosti.

Úlohy na zhotovení výrobku, který si sami navrhnou (práce velmi blízká práci konstruktéra a vynálezce).

Úlohy na zlepšení a zdokonalení výrobku.

\section{Technologické úlohy}

Úlohy na výběr materiálu, nástrojů a volba konkrétního postupu při výrobě určitého výrobku. Úlohy tohoto typu mohou žáci řešit ve chvíli, kdy si osvojili vlastnosti a použití př́slušných technických materiálů a vytvořili si dovednost v používání vybraných nástrojů pro práci s těmito materiály. Při volbě výrobního postupu je třeba, aby si žáci představili, jak se bude měnit design výrobku a jeho vlastnosti. $\mathrm{Na}$ základně těchto poznatků zvolili co nejefektivnější postup.

\section{Ekonomické úkoly}

Tyto úkoly jsou zaměřeny na organizaci práce. Jejich cílem je dosáhnout co nejefektivnějšího vykonání určité činnosti v co nejkratším čase při dosažení maximální kvality výrobku.

Další členění technických úloh reflektuje taxonomii plnění kognitivních cílů $\mathrm{v}$ pracovních činnostech a míru využití tvořivých schopností žáků (Kožuchová, 1995):

4. Úlohy teoreticko- poznávací- jsou zaměřeny na osvojení základních poznatků z technických disciplín. Ty mohou být:

- analyticko - popisné (odhalení prvků celku, popř́padě souvislostí,...atd.)

- studie historie technických vynálezů (odhalení znakủ, které dopomohli k vynálezu,...atd.).

\section{5. Úlohy prakticko- poznávací}

- Úlohy zaměřené na ovládání a demontáž technických zařízení s cílem odhalit konstrukční řešení,

- úlohy na sestavení modelů různých technických zařízení, 
- úlohy na experimentování, zaměřené na hledání nejvhodnějšího řešení technického problému, např. možnosti využití poznaných materiálů, experimenty při sestavování technických zařizení, úlohy na hledání neoptimálnějších technologických postupů.

6. Úlohy manipulačně- analytické- zkoumání teoretických základů techniky na konkrétních technických objektech a modelech.

7. Úlohy na rozvoj elaborace- úlohy na dotvoření nebo přetvoření výrobkủ po konstrukční, estetické, technologické nebo ekonomické stránce.

8. Úlohy na rozvoj redefinice (vynalézavosti)úlohy na změnu funkce technického předmětu a jeho využití jiným způsobem.

9. Úlohy na rozvoj originálních (nových, nezvyklých, netradičních) řešení- úlohy na schopnost vytvořit zvláštní, nová řešení technických problémů.

Určitým zjednodušením členění úloh je náš návrh rozdělení do dvou základních skupin (Pecina, 2005):

1. Úlohy teoretické- žáci řeší problém libovolného charakteru (úlohy na rozvoj fluence, flexibility, originality, elaborace, redefinice, představivosti, ....atd.). Tyto úlohy řeší pouze „na papíře" nebo na tabuli s pomocí různých modelů, obrazů nebo jiných pomůcek.

2. Úlohy praktické- žáci řeší problém praktického charakteru (zapojování obvodů, sestavování modelů, montáž a demontáž technických zařízení, zhotovení libovolného výrobku). Tato skupina obsahuje i úlohy první skupiny, protože žáci řeší problém nejprve teoreticky a potom prakticky. Přitom využívají znalosti o technických materiálech a jejich aplikacích, znalosti o nástrojích a technologických postupech.

Tvưrčí schopnosti lze rozvíjet divergentními úlohami, které rozvíjí i další psychické funkce. $\mathrm{Za}$ účelem komplexního rozvoje osobnosti by však mělo být rozvíjeno zejména divergentní a hodnotící myšlení (Zelina, Zelinová, 1990). Divergentní úlohy mohou mít následující podobu:

- Vymysli co nejvíc výrobků ze dřeva.
- Vymysli různé možnosti využití krabičky od čaje.

- Navrhni, k jakým účelům je možné využít kladivo.

- Popište ideální automobil.

- Vymysli, co by se stalo, kdyby přestala existovat elektřina.

U tvořivých úkolů nejde pouze o množství vyprodukovaných nápadů, ale také o jejich bohatost a proměnlivost. Neméně důležité jsou originální nápady, které se ve skupině bud' vyskytly jen jednou nebo v malém počtu. Dále je třeba s nápady pracovat, kombinovat je, zhodnotit a vybrat ty nejlepší.

\section{Závěr}

Praktické tvořivé úkoly technického charakteru mohou mít rozmanitou podobu. Základním momentem je problémová situace, kterou žáci následně řeší nejprve teoreticky (uvažování o problému, návrhy řešení) a poté prakticky (ověřování a realizace návrhů). Tyto úkoly se mohou vztahovat $\mathrm{k}$ různým oblastem: práce stechnickými materiály, práce elektrotechnické, manipulování, laborování, měření, práce se stavebnicemi apod. Náměty pro výuku nalézáme ve starších i novějších pramenech (Okoň, 1966,Zelina, Zelinová, 1990, Kožuchová,1995, Pecina, 2008, Pecina, Zormanová, 2009).

\section{Literatura:}

(1) HANDE, W. Gestaltung schöpferischtechnischer Schülertätigkeiten beim Experimentieren In. Eksperymenty uczniow $W$ nauczaniu techniki.Zielona Gora: WSzP, 1985, s. $79-91$.

(2) KOŽUCHOVÁ, M. Rozvoj technickej tvorivosti. Bratislava: UK, 1995. ISBN 80-2230967-2.

(3) KOŽUCHOVÁ, M. POMŠÁR, Z. KOŽUCH, I. Fenomén techniky vo výchove a vzdělávání v základném škole. Bratislava: UK, 1997. ISBN 80-223-1135-9.

(4) KROPÁČ, J., KUBÍČEK, Z., CHRÁSKA, M., HAVELKA, M. Didaktika technických předmětù vybrané kapitoly. Olomouc: UP, 2004. ISBN 80-244-0848-1

(5) LOKŠOVÁ, I. - LOKŠA J. Tvořivé vyučování. Praha: Grada Publishing, 2003.

ISBN 80-247-0374-2.

(5) MAŇÁK, J. Rozvoj aktivity, samostatnosti, a tvořivosti žáků. Brno: MU,1998. ISBN 80-2101880-1. 
(6) NOVOTNÝ, J., ZUKERSTEIN, J. Rozvoj technicky orientované tvořivosti pomocí projektových metod In: $X X V$. Mezinárodni kolokvium o řizení osvojovacího procesu zaměrené k aktuálním problémům vědy, výchovy, vzdělávání a rozvoje tvuirčího myšlení. Brno: Univerzita obrany, 2007. ISBN 978-80-7231228-3.

(7) OKOŇ. W. Kzákladi̊m problémového vyučování. Praha: SPN, 1966.

(8) PECINA, P. Vliv problémových metod výuky na rozvoj technické tvořivosti žáků.Disertačni práce.Brno:PdF MU,2005.

(9) PECINA, P. Tvořivost ve vzděláváni žáků. Brno: PdF MU, 2008. ISBN 978-80-210-4551-4. (10) PECINA, P. ZORMANOVÁ, L. Metody a formy aktivní práce žáků v teorii a praxi. Brno: MU, 2009. ISBN 978-80-210-4834-8

(11) SMÉKAL, V. Tvořivost a škola In KOLEKTIV. Tvořivost v práci učitele a žáka. Brno: Paido, 1996, s. 7-15

(12) ŠVEC,V. Kličové dovednosti ve vyučování a výcviku. Brno: MU, 1998. ISBN 80-210-19379.
(13) ZELINA, M. ZELINOVÁ, M. Rozvoj tvořivosti dětí a mládeže. Bratislava: SPN, 1990. ISBN 80-08-00442-8.

Mgr. Pavel Pecina, Ph.D.

Katedra didaktických technologií

Pedagogická fakulta Masarykovy univerzity

Poříćí 31

602 00, Brno

Česká republika

Telefon. +420549495488

Mail: ppecina@ped.muni.cz

Mgr. Silvie Malá

Pedagogická fakulta Masarykovy univerzity

Pořící 31

602 00, Brno

Česká republika

Telefon: +420606 315499

Mail: silvie.mala@centrum.cz 